\title{
REGRESYON ANALIZLERININ MUHASEBE MESLEK MENSUPLARINA VE ÖĞRENCILLEIINE YÖNELİK ÇALIŞMALARDA KULLANIMI: BİR ALAN YAZIN TARAMASI
}

\section{Süleyman ŞAHIN}

Dr. Öğr. Üyesi, Bolu Abant İzzet Baysal Üniversitesi, İ.İ.B.F., İşletme Bölümü, suleymansahin@ibu.edu.tr., Orcid No: 0000-0001-9621-430X

\section{Hakan BİLEN}

Doktora Öğrencisi, Bolu Abant İzzet baysal Üniversitesi, Lisansüstü Eğitim Enstitüsü, Sosyal Bilimler, İşletme Programı, bilenhakan14@gmail.com., Orcid No: 0000-0002-9482-9519 


\title{
REGRESYON ANALIZLLERININ MUHASEBE MESLEK MENSUPLARINA VE ÖĞRENCILERIINE YÖNELIK ÇALIŞMALARDA KULLANIMI: BİR ALAN YAZIN TARAMASI
}

$\ddot{O} \mathbf{z}$

Günümüz işletmelerinin uluslararası pazarlarda küreselleşme sürecinde faaliyet göstermeleri, finansal tablolardan elde edilen bilgiye olan ihtiyacı artırmıştır. Nitekim bu durum, muhasebe biliminin, eğitiminin, mesleğinin ve muhasebe meslek mensuplarının önem kazanmasını sağlamıştır. Bu çalışmada muhasebe eğitimi alan öğrencilerin muhasebe derslerine yönelik başarılarını, muhasebe mesleğini seçmelerini etkileyen faktörleri inceleyen çalışmalar ile muhasebe meslek mensuplarının iş tatminini, performansını ve başarısını etkileyen faktörleri inceleyen, regresyon analizi kullanılan çalışmalar incelenmiştir. Bu doğrultuda ilgili alanlarda yerli ve yabancı literatürde yapılmış çalışmalar derlenerek muhasebe meslek mensuplarının ve muhasebe eğitimi alan ögrencilerin kariyer süreçlerine yönelik objektif bilgiler sunulmuştur.

Anahtar Kelimeler: Regresyon Analizi, Muhasebe Mesleği, Muhasebe Kariyeri, İş Tatmini, İş Performansı,

\section{THE USE OF REGRESSION ANALYSIS IN STUDIES OF ACCOUNTING PROFESSIONALS AND STUDENTS: A FIELD REVIEW}

\begin{abstract}
The fact that today's businesses operate in international markets in the globalization process has increased the need for information obtained from financial statements. As a matter of fact, this situation has made accounting science, education, profession and accounting professionals gain importance. In this study, studies that examine the success of accounting students in accounting courses and the factors that affect their choice of accounting profession, and the studies that examine the factors affecting the job satisfaction, performance and success of accounting professionals, using regression analysis were examined. In this direction, by compiling the studies conducted in the relevant fields in the domestic and foreign literature, objective information about the career processes of accounting professionals and students who receive accounting education is presented.
\end{abstract}

Key Words: Regression Analysis, Accounting Profession, Accounting Career, Job Satisfaction, Job Performance, 


\section{GíRIŞ}

Küreselleşme olgusu günümüz sosyal, kültürel ve ekonomik hayatını etkileyen en önemli olgulardan birisidir. Küreselleşen dünyada, işletmelerin tüm ülkelerde tek bir pazar gibi faaliyet göstermeleri çok uluslu şirketlerin varlığını artırmıştır. Uluslararası yatırımlarda meydana gelen artış, küresel anlamda finansal piyasaların önem kazanmasını sağlamıştır. $\mathrm{Bu}$ artışla birlikte küresel sermayenin tüm ülkelerde yaygınlaşması iş dünyasında karşılaştırılabilir, şeffaf ve evrensel bir finansal raporlama sistemine olan ihtiyacı artırmıştır (Erdoğan ve Dinç, 2009: 154; Türker, 2018: 206). Nitekim bu ihtiyaç doğrultusunda, Uluslararası Muhasebe Standartları Komitesi (IFAC) tarafından, Uluslararası Muhasebe Standartları hazırlanmıştır (Güneş vd., 2012: 62). Bununla birlikte, bilişim ve iletişim teknolojilerinde yaşanan gelişmelerin muhasebe uygulamalarını da etkisi altına alması, muhasebe uygulamalarının internet gücüne dayalı, eskisinden daha hızlı, etkili ve verimli bir şekilde yerine getirilmesini sağlamıştır (Hacırüstemoğlu, 2009: 22).

Muhasebe uygulamaları alanında yaşanan bu gelişim ve ilerlemeler, muhasebe mesleğinin, muhasebe eğitiminin ve bu mesleği ifa eden muhasebe meslek mensuplarının öneminin artmasına neden olmuştur. Nitekim muhasebe meslek mensupları, işletmelerde gerçekleşen mali nitelikli olaylar doğrultusunda finansal bilgi kullanıcılarının ihtiyaçlarına uygun bilgiyi üretirken aynı zamanda sosyal sorumluluk duygusuyla hareket etmelidirler. Zira muhasebe meslek mensupları tarafından üretilen bilgilerin bilerek veya bilmeyerek hatalı bir şekilde elde edilmesi, ekonomik kaynakların dağılımını ve muhasebe meslek mensuplarına duyulan güveni olumsuz bir şekilde etkileyecektir (Ayboğa, 2003: 332).

Küreselleşmeyle birlikte işletmelerin uluslararası pazarlarda faaliyet göstermeye başlamaları günümüz işletme faaliyetlerinin karmaşık bir hal almasına ve beraberinde muhasebe meslek mensupları tarafından üretilen bilgiye duyulan ihtiyacın artmasına neden olmuştur. Bununla birlikte vergi mevzuatında yaşanan değişiklikler ve mükelleflerin beklentileri de muhasebe meslek mensuplarının iş yükünü artırmanın yanı sıra sürekli olarak kendilerini geliştirmelerini de gerektirmektedir (Aydemir, 2015: 72). Muhasebe meslek mensupları görevlerini ifa ederken mükellefler, yasalar, meslektaşlar, çalışma ortamı, sosyal çevre gibi faktörlerden dolayı çeşitli sorunlarla karşılaşabilmektedir. Bu sorunlar kimi zaman performans düşüklüğü, mükellefe veya devlete verilen hizmet kalitesinde düşme veya meslekten ayrılma ile sonuçlanırken kimi zaman muhasebe mesleğine aykırı işlemler yapma gibi durumlarla sonuçlanmaktadır (Gündüz ve Özen, 2016: 68). Özellikle, 21. yüzyılın başlarında Enron, Parmalat, Xerox gibi şirketlerde meydana gelen muhasebe skandallarında şirketlerin muhasebe birimi çalışanlarının ve bağımsız denetim firmalarının gerçekleştirilen hileli finansal işlemlerde yardımcı rol üstlenmesi muhasebe mesleğine ve muhasebe meslek mensuplarına duyulan güveni zedelemiştir (Türel, 2011: 9-12).Bu bağlamda muhasebe eğitimi alan öğrencilere muhasebe ile ilgili teknik bilginin yanı sıra meslek etiği ve ahlakı ile ilgili gerekli eğitimlerin de verilmesi muhasebe mesleğinin itibarı açısından oldukça önemlidir.

Regresyon analizi, aralarında sebep sonuç ilişkisi bulunan iki veya daha fazla değişken arasındaki ilişkiyi incelemek amacıyla kullanılan istatistiksel bir yöntemdir (Altunışık vd., 2010: 231). Nakip (2013: 332)'e göre regresyon analizi, iki değişken arasında birlikte bir değişim olup olmadığını göstermektedir. Bir bağımlı değişken ile bir bağımsız değişken arasındaki ilişki inceleniyorsa tek değişkenli regresyon analizi, bir bağımlı değişken ile birden fazla bağımsız değişken arasındaki ilişki inceleniyorsa çok değişkenli regresyon analizi yöntemlerinden yararlanılır (Altunışık vd., 2010: 231237).

Mühendislik, tıp, psikoloji, pazarlama, finans vb. birçok alanda yapılan çalışmalarda istatistiksel veri analiz yöntemi olarak kullanılan regresyon analizi, muhasebe alanında yapılan birçok çalışmada da analiz yöntemi olarak kullanılmaktadır. Nitekim bu çalışmada Türkiye literatüründe ve yabancı literatürde muhasebe eğitimi alan öğrencilerin muhasebe derslerine yönelik başarılarını, muhasebe mesleğini, muhasebe kariyerini seçmelerini etkileyen faktörleri inceleyen çalışmalar ile muhasebe meslek mensuplarının iş tatmini, iş performansı, iş başarısına yönelik yapılan ve regresyon analizi yöntemi kullanılan çalışmalar incelenmiştir. İncelenen çalışmaların sıralamasında kronolojik tarih baz alınmıştır. Çalışmada, muhasebe meslek mensuplarının ve muhasebe eğitimi alan öğrencilerin kariyer süreçleri ile ilgili objektif kararlar vermelerinin yanı sıra bu alanda çalışmalar yapacak olan araştırmacılara, akademisyenlere ve ögrencilere bütünleşik bir kaynak oluşturmak amaçlanmıştır. 


\section{REGRESYON ANALİİ VE KULLANILAN BAZI YÖNTEMLER/MODELLER}

Birçok alanda yaygın olarak kullanılmakta olan regresyon analizi, aralarında sebep-sonuç ilişkisi bulunan iki veya daha fazla değişken arasındaki ilişkiyi inceleyen ve bu ilişkiyi modellemek için kullanılan istatistiksel bir analiz yöntemdir (Vural, 2007: 2).

$\mathrm{Bu}$ yöntem, herhangi bir bağımlı değişkenin bir veya birden fazla bağımsı-açıklayıcı değişkenle arasındaki ilişkinin $(\mathrm{Y}=\mathrm{a}+\mathrm{bx})$ biçiminde matematiksel bir fonksiyon olarak yazılmasıdır. Regresyon denklemi yardımıyla bağımsız-açıklayıcı değişkenlerin çeşitli değerlerine karşılık gelen bağımlı değişkenin ulaşacağ değer tahmin edilmeye çalışılır. Regresyon analizi, tek bağımsız değişken varsa; "Basit Regresyon Analizi", birden çok bağımsız değişken varsa; "Çoklu Regresyon Analizi" olmak üzere iki grupta ele alınır. Fonksiyon tipine göre ise "Doğrusal Regresyon Analizi" ve "Doğrusal Olmayan Regresyon Analizi” olmak üzere iki grupta toplanır (Orhunbilge, 2017: 2).

Regresyon analizinde birçok yöntem/model kullanılmaktadır. Bunlardan bazılarını kısaca şöyle ifade edebiliriz:

Basit regresyon modeli, cevap aranan (bağımlı) değişken ile bir tane bağımsız (açıklayıcı) değişken arasındaki doğrusal ilişkiyi ifade eder. Şayet tek bir bağımlı değişken ve birden fazla bağımsız değişken arasındaki doğrusal olan veya olmayan bir ilişkinin belirlenmesi istenirse, bu tarz bir ilişki çoklu doğrusal regresyon analizi ile incelenir kullanılmaktadır (Arı ve Önder, 2013).

Lojistik regresyon yöntemi, iki ya da daha fazla sınıfta ifade edilebilen kesikli verilerde bağımsız değişken (Y) için istatistiksel bir model oluşturma tekniğidir. Bağımlı değişkenin kesikli olduğu durumlar için Lojistik ya da Probit regresyon yöntemleri kullanılmaktadır (Arı ve Önder, 2013).

Probit regresyon modeli, lojistik regresyona alternatif olarak bir veya daha fazla açıklayıcı değişkenin kategorik bir yanıt değişkeni (sağ, ölü; çalışıyor, çalışmıyor, ürün satıldı veya satılmadı vb.) üzerindeki etkisini bulmak için kullanılan bir modeldir. Hem lojistik hem de Probit regresyon analizi birbirlerine oldukça benzer ve elde edilen olasılık tahminleri birbirlerine yakın değerdedir. Lojistik regresyon analizinde log-odds (olabilirlik oranları) kullanılırken, Probit modelinde kümülatif normal dağılım kullanılmaktadır, Temel olarak Probit birikimli standart normal dağılışın tersidir (Topcu, 2008: 207).

Poisson regresyon modeli, Araştırmadan elde edilen verilerin ölçeğinin sürekli yapıda olmadığı, kategorik veriye sahip olunduğu durumlarda doğrusal regresyon modelleri kullanılarak yapılacak analizler etkisiz, tutarsız ve güvenilmez sonuçlar verebilir. Özellikle, sayma ölçeğinde elde edilen veriler için kullanılabilecek en etkin modellerden biri Poisson regresyon modelidir (Deniz, 2005: 60).

Negatif Binom regresyon modeli, Poisson regresyonun özel bir durumudur. Bu iki model arasındaki seçim kararı, kestirimi elde edilen d katsayısının istatistiksel anlamlılığı yönünden belirlenir. Eğer d (yayılım parametresi), sıfırdan önemli derecede farklı değilse (istatistiksel olarak önemli değilse), Negatif Binom regresyonu Poisson regresyonuna dönüşür. Bununla beraber, $d$ önemli derecede sıfirdan farklı ise, Negatif Binom regresyonu tercih edilmelidir (Aktaş ve Saraçbaşı, 2005). Negatif Binom modeli, regresyonunun uygulandığı veri kümesinde değerlerin çoğunun sıfır olmasından dolayı dağılış sağa çarpıktır. Bu durum, doğrusal regresyon kullanımında kuramsal olarak hatalı olan negatif parametre tahminlerini beraberinde getirmektedir (Cox, 1983: 271).

Temel bileşenler regresyon yöntemi, her doğrusal regresyon modelinin bir dik açıklayıcı değişkenler kümesine dayanarak yeniden açıklanması temeli üzerine yapılandırılmış olup, açıklayıcı değişkenler arasında çoklu bağlantı olduğu durumlarda uygulanmaktadır (Özkan, 2009: 3). Çünkü çoklu regresyon analizinde, değişkenler arasında bir ya da daha fazla doğrusal ilişki olması halinde çoklu bağlantı sorunu ortaya çıkmaktadır.

\section{ARAŞTIRMANIN YÖNTEMI}

Çalışma, muhasebe literatürü dikkate alınarak hazırlanmıştır. $\mathrm{Bu}$ doğrultuda Türkiye literatüründe ve yabancı literatürde muhasebe eğitimi alan öğrencilerin muhasebe derslerine yönelik başarılarını, muhasebe mesleğini, muhasebe kariyerini seçmelerini etkileyen faktörleri inceleyen çalışmalar ile muhasebe meslek mensuplarının iş tatmini, iş performansı, iş başarısına yönelik olarak yapılan ve regresyon analizi yöntemi kullanılan çalışmalar incelenmiştir. $\mathrm{Bu}$ doğrultuda ilgili 
çalışmaların elde edilmesinde arama motorları ve veri tabanlarından yararlanılmıştır. İlgili çalışmalar, muhasebe mesleği (accounting profession), muhasebe kariyeri (accounting career), iş tatmini (job satisfaction), iş performansı (job performance), regresyon analizi (regression analysis) anahtar kelimeleri aracılığıyla belirlenmiş ve incelenmiştir. Çalışmaların özellikle güncel yayınlar olmasına dikkat edilmiş ve incelenen çalı̧̧maların sıralamasında kronolojik tarih dikkate alınmıştır

\section{YAPILAN ÇALIŞMALARA YÖNELIK ALAN YAZIN TARAMASI}

Harun (2020), Endonezya' da öğrenim gören ve muhasebe eğitimi alan üniversite öğrencilerinin kariyer seçimini ve nitelikli bir muhasebeci olmalarını etkileyen faktörleri incelemek amacıyla bir çalışma yapmıştır. Bu bağlamda Endonezya'da faaliyet gösteren devlet üniversiteleri ve özel üniversitelerde öğrenim gören ve muhasebe eğitimi alan 374 öğrenciye anket çalışması uygulanmıştır. Çalışmada uygulanan analiz sonuçları neticesinde elde edilen bulgulara göre muhasebe mesleğinin kişilere meslekte ilerleme firsatı vermesinin, muhasebe mesleği seçiminde olumlu bir etkisi olduğu belirlenmiştir. Bununla birlikte muhasebe mesleğinin kişilere sunduğu kazanç durumu ile muhasebe mesleğine yönelik kişisel algıların meslek seçiminde bir etkisi olmadığı da çalışmada tespit edilen diğer önemli sonuçlardır.

Abdelmoula (2020) dışsal iş memnuniyeti faktörlerinin (şirket politikaları, çalışanların iş arkadaşları ve amirleriyle olan ilişkileri, iş güvenliği, maaş, çalışma koşulları) muhasebe meslek mensuplarının örgütsel bağlılıkları üzerindeki etkisini incelemek amacıyla bir çalışma yapmıştır. $\mathrm{Bu}$ doğrultuda Tunus'ta çalışan 140 muhasebe meslek mensubuna anket çalışması uygulanmış ve elde edilen veriler analize tabi tutuluştur. Çalışmada uygulanan korelasyon analizi sonuçlarına göre şirket politikaları, muhasebe meslek mensuplarının iş arkadaşları ve amirleriyle olan ilişkileri, iş güvenliği ve çalışma koşulları ile muhasebe meslek mensuplarının örgütsel bağlılıkları arasında anlamlı ve pozitif bir ilişki tespit edilmiştir. Ayrıca regresyon analizi sonuçlarına göre şirket politikaları, çalışma koşulları, muhasebe meslek mensuplarının iş arkadaşları ve amirleriyle olan ilişkileri muhasebe meslek mensuplarının duygusal ve normatif bağlıkları üzerinde olumlu bir etkiye sahiptir.

Nguyen (2020) yaptığı çalışmada muhasebe meslek mensuplarının iş tatminini etkileyen faktörleri incelemiştir. Bu doğrultuda Vietnam'da çalışan 200 muhasebe meslek mensubuna anket çalışması uygulanmış, 145 muhasebe meslek mensubundan elde edilen veriler analiz edilmiştir. Çalışmada elde edilen bulgulara göre muhasebe meslek mensuplarının maaşlarının, başarıları neticesinde çalıştıkları kurumdan maddi ve manevi anlamda aldıkları ödül ve terfilerin, çalışma koşullarının iş tatmini üzerinde olumlu etkiye sahip olduğu tespit edilmiştir. Bununla birlikte iletişim ve bilgi teknolojilerinde meydana gelen gelişmelerin muhasebe uygulamalarını da etkilediği, dolayısıyla işletmelerin bu gelişmeleri dikkate alarak personel seçimini gerçekleştirmeleri gerekliliği de belirtilmiştir.

Hasim vd., (2020) Endonezya'da öğrenim gören ve muhasebe eğitimi alan üniversite öğrencilerinin muhasebe mesleğine yönelik algılarını etkileyen faktörleri incelemek amacıyla bir çalışma yapmışlardır. Bu doğrultuda, Endonezya'da UNISDA ve UNISLA üniversitelerinde öğrenim gören ve muhasebe eğitimi alan 115 öğrenciye anket uygulanmıştır. Çalışmada uygulanan analiz sonuçlarına göre öğrencilerin muhasebe mesleğine yönelik algıları yüksek maaş, refah seviyesindeki artış gibi finansal ödüller ile öğrencinin rol model aldığı aile, arkadaş gibi sosyal değerleri etrafında şekillenmektedir. Dolayısıyla bu iki faktör öğrencilerin kariyer seçimi üzerinde olumlu bir etkiye sahiptir. Bununla birlikte çalışmada muhasebe mesleğinin çalışma ortamının meslek seçiminde herhangi bir etkiye sahip olmadığ belirtilmiştir.

Demir ve Temelli (2019) muhasebe eğitimi alan üniversite öğrencilerinin, muhasebe eğitimine yönelik motivasyon ve beklentilerinin, eğitim aldıkları bölüme olan ilgileri üzerindeki etkilerini incelemek amacıyla bir çalışma yapmışlardır. Bu doğrultuda, Ağrı İbrahim Çeçen Üniversitesi İktisadi ve İdari Bilimler Fakültesi İşletme Bölümü ve Ağrı İbrahim Çeçen Üniversitesi Meslek Yüksekokulu Muhasebe ve Vergi Programı öğrencilerine yönelik anket çalışması uygulanmıştır. 146 öğrenciden elde edilen veriler öğrencilerin muhasebe eğitimine yönelik motivasyonlarının ve beklentilerinin, eğitim gördükleri bölüme yönelik ilgileri üzerindeki etkilerini incelemek amaciyla regresyon analizine tabi tutulmuştur. Analiz sonuçlarına göre, muhasebe eğitimi alan üniversite öğrencilerinin motivasyon ve beklentilerinin öğrenim gördükleri bölüme olan ilgileri üzerinde olumlu bir etkisi olduğu belirtilmiştir. 
Apalı ve Acun (2019) muhasebe eğitimi alan öğrencilerin doğayı koruma bilinçlerinin yeşil muhasebeye yönelik algıları üzerindeki etkisini incelemek amacıyla bir çalışma yapmışlardır. Anket yönteminin kullanıldığı çalışmaya Burdur Mehmet Akif Ersoy Üniversitesi Bucak Hikmet Tolunay Meslek Yüksekokulu ve Sosyal Bilimler Meslek Yüksekokulu'nda öğrenim gören ve muhasebe eğitimi alan 138 ön lisans öğrencisi katılım göstermiştir. Çalışmada uygulanan regresyon analizi sonuçlarına göre muhasebe eğitimi alan üniversite öğrencilerinin doğayı koruma bilinçlerinin yeşil muhasebe ile ilgili olumlu yaklaşımlar üzerinde etkili olduğu sonucuna ulaşılmıştır. Çalışmada ayrıca yeşil muhasebe uygulamalarının biyoçeşitliliğin sürdürülmesinde, su kullanımı ve tasarrufu yönetiminde, işletme maliyetlerinin düşürülmesinde katkıları olacağı belirlenmiştir.

Cengiz ve Tekin (2019) muhasebe eğitimi alan üniversite öğrencilerinde strese neden olan faktörlerle muhasebe derslerine yönelik tutumlarını incelemek amacıyla bir çalışma yapmışlardır. Çankırı Karatekin Üniversitesi İktisadi ve İdari Bilimler Fakültesi öğrencileri çalışmanın evrenini oluşturmaktadır. 238 öğrencinin katılımıyla elde edilen verilere t testleri, tek yönlü varyans analizi, korelasyon ve regresyon analizi uygulanmıştır. Çalışmada elde edilen sonuçlara göre öğrencilerin gelecek kaygıları, derse yönelik olumlu tutum düzeylerini; öğrencilerin sosyal çevreleri ve derslerle ilgili olarak stres yaşamaları derse yönelik tutumlarını ve öğrencilerin sosyal çevreleri ve derslerin zorluğu nedenleriyle yaşadıkları stres derse yönelik tutumlarını olumsuz etkilemektedir.

Durgut ve Pehlivan (2019) muhasebe eğitimi alan öğrencilerin muhasebe alanına yönelme nedenlerini, kariyer beklentilerini ve meslek seçimini etkileyen faktörlerle olan ilişkisini incelemek amacıyla bir çalışma yapmışlardır. Çalışmanın evrenini Giresun Üniversitesi Muhasebe ve Vergi bölümünde öğrenim gören öğrenciler oluşturmaktadır. Çalışmada; kariyer beklentisi, itibar/prestij, maaş, çalışma ortamı ve iş güvenliği gibi faktörlerin meslek seçimini etkileyen önemli faktörler olduğu belirlenmiştir. Bununla birlikte, gerçekleştirilen regresyon analizi sonuçlarına göre öğrencilerin kariyer seçimini etkileyen faktörlere verdikleri puanların iş seçim tercihlerini etkilediği tespit edilmiştir.

Temelli (2019) Ağrı İbrahim Çeçen Üniversitesi İktisadi ve İdari Bilimler Fakültesinde öğrenim gören ve muhasebe eğitimi alan öğrencilerin muhasebe derslerinde teknoloji kullanımına yönelik algılarının derse odaklanma ve derse olan ilgileri üzerindeki etkisini incelemek amacıyla bir çalışma yapmıştır. 164 öğrencinin katılım gösterdiği anket çalışması neticesinde elde edilen verilerin analiz sonuçlarına göre muhasebe derslerinde teknoloji kullanımının öğrencilerin derse olan ilgisini artırdığı tespit edilmiştir. Bununla birlikte özellikle muhasebe ve finans derslerinde çeşitli problem ve formül anlatımlarında öğretim elemanı kalitesine de vurgu yapılmıştır. Öğretim elemanları tarafindan teknolojinin yoğun bir şekilde kullanımının öğrencilerin derse olan ilgisini ve beraberinde akademik başarısını artıracağı belirtilmiştir.

Srirejeki vd., (2019) Endonezya'da öğrenim gören ve muhasebe eğitimi alan üniversite öğrencilerinin kariyer süreçlerini etkileyen faktörleri incelemek amacıyla bir çalışma yapmışlardır. 439 öğrencinin katılım gösterdiği çalışmada geçerlilik ve güvenilirlik analizleri, tanımlayıcı analizler, lojistik regresyon analizi gibi analiz yöntemlerinden yararlanılmıştır. Çalışmada, regresyon analizi sonuçlarına göre muhasebe mesleğinin bireylere iyi bir kariyer gelişimi ve bireylerin refah seviyesini yükseltecek finansal özgürlük sunmasının muhasebe alanında kariyer yapma düşüncesini olumlu anlamda etkilediği sonucuna ulaşılmıştır.

Kılınçarslan ve Küçüksüleymanoğlu (2019) muhasebe meslek mensuplarının örgütsel bağlılıklarının iş tatmini üzerine etkisini incelemek amacıyla bir çalışma yapmışlardır. Bursa İl'inde faaliyet gösteren 342 muhasebe meslek mensubunun katılım gösterdiği çalışmada çoklu regresyon analizi yöntemi kullanılmıştır. Çalışmada; örgütsel bağlılı̆̆ın alt boyutları olan duygusal, devam ve normatif bağlılı̆̆ın dişsal tatmin üzerinde anlamlı etkisi olduğu tespit edilmiştir. Bununla birlikte duygusal ve devam bağlılığının içsel tatmini pozitif anlamda etkilediği ancak normatif bağlılığın içsel tatmin üzerinde herhangi bir etkisi olmadığ

Tekin ve Deniz (2019) kontrol odağının muhasebe meslek mensuplarının iş stresi, iş performansı ve iş tatmini üzerindeki etkisini incelemek amacıyla bir çalışma yapmışlardır. Kolayda ve kartopu örnekleme yöntemlerinin kullanıldığ çalışmada 178 muhasebe meslek mensubuna anket çalışması uygulanmıştır. Elde edilen verilerin analizinde faktör analizi, tanımlayıcı istatistiki analizler, geçerlilik ve güvenilirlik analizleri, hipotezlerin test edilmesinde $t$ testi, korelasyon analizi ve regresyon 
analizi yöntemlerinden yararlanılmıştır. Çalışmada uygulanan basit doğrusal regresyon analizi sonuçlarına göre iç kontrol odaklılığın iş tatmini üzerinde pozitif, iş stresi üzerinde ise negatif etkiye sahip olduğu tespit edilmiştir. Yine çalışmaya göre dış kontrol odaklılığı iş tatmini üzerinde negatif, iş stresi üzerinde pozitif bir etkiye sahiptir.

Mosuin vd., (2019) muhasebe sistemlerinin kabul seviyesinin muhasebe meslek mensuplarının motivasyonlarına, performanslarına ve iş memnuniyetine olan etkilerini incelemek amacıyla bir çalıșma yapmışlardır. Çalışmanın verilerini Malezya'da kamu sektöründe muhasebe meslek mensubu olarak çalışan 202 meslek mensubundan anket yöntemi aracılığıyla elde edilen veriler oluşturmaktadır. Çalışmada gerçekleştirilen regresyon analizi sonuçlarına göre; muhasebe sistemlerinin kabul seviyesinin muhasebe meslek mensuplarının motivasyonları, iş tatmini ve iş performansı üzerinde olumlu bir etkiye sahip olduğu belirtilmiştir. Çalışmada ayrıca muhasebe meslek mensuplarının çalışma koşullarının iyileştirilmesinin, meslek mensuplarına kurum içi eğitimler düzenlenmesinin ve teknolojik imkânlar sunulmasının muhasebe meslek mensuplarının iş tatmini ve performanslarının üst düzeye çıkarılmasında etkili olduğu belirtilmiştir.

Arif vd., (2019) Pakistan'da öğrenim gören öğrencilerin muhasebe mesleğini seçmelerini etkileyen faktörleri incelemek amacıyla bir çalışma yapmışlardır. Anket yöntemi kullanılan çalışmada, Pakistan'da sekiz farklı bölümde öğrenim gören ve muhasebe eğitimi alan 300 öğrenci katılım göstermiştir. Çalışmada öğrencilerin öz yeterliliği, sosyal ve ekonomik çevresi, akademik süreç boyunca aldıkları desteklerin muhasebe ile ilgili kariyer yapma düşüncelerini olumlu yönde etkilediği belirtilmiştir. Bununla birlikte cinsiyet ve ailenin gelir seviyesi gibi demografik değişkenlerin kariyer süreci üzerinde herhangi bir etkisi olmadığı tespit edilmiştir.

Shan vd., (2019) Malezya' da öğrenim gören ve muhasebe eğitimi alan üniversite öğrencilerinin "iç denetçi”" mesleğine yönelik bakış açılarını incelemek amacıyla bir çalışma yapmışlardır. 198 öğrencinin katılım gösterdiği çalışmada uygulanan regresyon analizi sonuçlarına göre öğrencilerin mesleğe yönelik bireysel ilgilerinin iç denetçi mesleğine yönelik algıları üzerinde olumlu ve güçlü bir etkiye sahip olduğu belirtilmiştir. Bununla birlikte öğrencilerin öğrenim görülen bölüm ve aile, arkadaş çevrelerinin de nispeten meslek seçimini olumlu yönde etkilediği tespit edilmiştir.

Aksu ve Tursun (2018) Adıyaman Üniversitesi İktisadi ve İdari Bilimler Fakültesi’nde öğrenim gören ve muhasebe eğitimi alan üniversite ögrencilerinin motivasyon ve beklentilerinin akademik başarıları üzerindeki etkisini incelemek amacıyla bir çalışma yapmışlardır. Veri toplama yöntemi olarak anket yönteminin uygulandığı çalışmaya 124 öğrenci katılım göstermiştir. Çalışmada, öğrencilerin motivasyon ve mesleki beklentilerinin akademik başarılarını olumlu yönde etkilediği sonucuna ulaşılmıştır. Çalışmada ayrıca, öğrencilerin motivasyon ve beklenti seviyelerinin yükseltilmesi için ders dışı çeşitli etkinliklerin yapılmasının gerekliliği de vurgulanmıştır.

Özdemir vd., (2018) muhasebe eğitimi alan öğrencilerin matematiğe yönelik algılarını ve bu algıların muhasebedeki akademik başarı üzerindeki etkisini incelemek amacıyla bir çalışma yapmışlardır. Çalışmanın verilerini, On dokuz Mayıs Üniversitesi İktisadi ve İdari Bilimler Fakültesi'nde öğrenim gören sadece genel muhasebe dersini almış 122 öğrencinin geri dönüşüyle elde edilen anket formları oluşturmaktadır Çalışmada uygulanan lojistik regresyon analizi sonuçlarına göre bağımsız değişkenlerin (cinsiyet, lise öğrenim türü, mezun olunan lise, üniversite memnuniyeti, bölüm memnuniyeti, muhasebe ile ilgili derslerin sıklı̆̆ı, muhasebenin akademik kariyerdeki önemi, muhasebeyi matematiksel bir ders olarak görme, matematiği sevme) muhasebe başarısı üzerindeki etkisinin $\% 22,2$ ve $\% 30,8$ seviyelerinde olduğu tespit edilmiştir.

Temelli ve Çınar (2018), Ağrı İbrahim Çeçen Üniversitesi İktisadi ve İdari Bilimler Fakültesinde öğrenim gören, muhasebe eğitimi alan öğrencilerin maliyet muhasebesi dersine bakış açıları ile ders başarıları arasındaki ilişkiyi incelemek amacıyla bir çalışma yapmışlardır. Anket yönteminin uygulandığı, 126 öğrencinin katılım gösterdiği çalışmada, $t$ testi, anova testi, regresyon ve korelasyon analiz yöntemleri kullanılmıştır. Yapılan analizler neticesinde öğrencilerin maliyet muhasebesi dersine yönelik tutumlarında öğrenim gördükleri bölümün, mezun oldukları lise türünün, ailelerinin aylık gelirlerinin, ebeveynlerinin öğrenim durumlarının etkili olduğu ve öğrencilerin derse yönelik tutumların ders başarısını etkilediği sonucuna ulaşılmıştır. 
Bekoe vd., (2018) Gana'da öğrenim gören ve muhasebe eğitimi alan işletme bölümü öğrencilerinin muhasebe mesleğine yönelik tutumlarını incelemek amacıyla bir çalışma yapmışlardır. Gana'da çeşitli üniversitelerde öğrenim gören 457 öğrencinin katılım gösterdiği çalışmada veriler anket yöntemi aracılığıyla elde edilmiştir. Çalışmada uygulanan lojistik regresyon analizi sonuçlarına göre öğrencilerin kişisel yeteneklerinin ve aile, arkadaş, rol model alınan kişiler gibi sosyal çevreleri ile etkileşimlerinin muhasebe mesleğini yönelik tutumlarını olumlu yönde etkilediği tespit edilmiştir. Bununla birlikte çalışmada muhasebe mesleğinin çalışma koşulları ve mesleğin çekiciliğinin öğrencilerin meslek algıları üzerinde herhangi bir etkisi olmadığ çevrenin meslek tercihini etkilemesinden yola çıkılarak, Gana ve Çin kültürünün bu doğrultuda benzer özellikler sergilediği belirtilmiştir.

Herawati vd., (2018) Bali’de öğrenim gören ve muhasebe eğitimi alan üniversite öğrencilerinin finansal kararlarını ve davranışlarını etkileyen faktörleri incelemek amacıyla bir çalışma yapmışlardır. Bali'de çeşitli üniversitelerde öğrenim gören 518 öğrencinin katılım gösterdiği çalışmada veri toplama yöntemi olarak anket yönteminden yararlanılmıştır. Çalışmada, verilerin normal dağılıp dağılmadığını belirlemek amacıyla Kolmogorov-Simrnov testi uygulanmıştır. Çalışmada uygulanan çoklu regresyon analizi sonuçlarına göre bireylerin finansal okuryazarlık, finansal öz yeterlilik ve sosyal-ekonomik durumlarının finansal davranışları üzerinde pozitif ve anlamlı bir etkiye sahip olduğu tespit edilmiştir.

Büyükyılmaz vd., (2018) muhasebe meslek mensuplarının mesleki bağlllıklarının iş tatmini üzerine etkisini incelemek amacıyla bir çalışma yapmışlardır. Bartın, Karabük ve Zonguldak illerinde çalışan 573 muhasebe meslek mensubunun katılım gösterdiği çalışmada veriler anket yöntemi aracılığıyla elde edilmiştir. Çalışmada geçerlilik ve güvenilirlik analizi, faktör analizi tanımlayıcı istatistiksel analizler ile birlikte hipotezlerin test edilmesi için çoklu regresyon analizi uygulanmıştır. Çoklu regresyon analizi sonuçlarına göre muhasebe meslek mensuplarının mesleki bağl1lıklarının içsel ve dışsal iş tatmini olumlu ve pozitif bir şekilde etkilediği tespit edilmiştir.

Gör (2017), Çankırı Karatekin Üniversitesi İktisadi ve İdari Bilimler Fakültesinde öğrenim gören ve muhasebe eğitimi alan üniversite öğrencilerinin muhasebe eğitimine yönelik algılarını incelemek amacıyla bir çalışma yapmıştır. Çalışmada kadınların erkeklere oranla muhasebe mesleğine ilgi düzeylerinin daha yüksek olduğu,20 -22 yaş aralığında yer alan öğrencilerin muhasebe eğitimini devam ettirme isteklerinin daha yüksek olduğu ve çalışmada uygulanan regresyon analizi sonuçlarına göre öğrencilerin bireysel özelliklerinin muhasebeye yönelik algılarının belirlenmesinde önemli bir etken olduğu sonucuna ulaşılmıştır.

Çarıkçı (2017a), Süleyman Demirel Üniversitesinde öğrenim gören, muhasebe eğitimi alan üniversite öğrencilerinin muhasebe alanına yönelik tutumlarını belirlemek ve bu tutumların muhasebe alanında çalışma niyetlerine etkisini incelemek amacıyla bir çalışma yapmıştır. 960 öğrencinin katlım gösterdiği çalışmada, öğrencilerin bireysel özelliklerinin muhasebe alanında çalışmayı etkileyen en önemli faktör olduğu sonucuna ulaşılmıştır. Çalışmada ayrıca ticaret lisesi mezunu öğrencilerin diğer lise mezunlarına göre muhasebe alanına olan ilgilerinin daha yüksek olduğu belirtilmiştir.

Çarıkçı (2017b) muhasebe eğitimi alan öğrenciler üzerine yaptığı bir başka çalışmada, öğrencilerin muhasebe bölümünü seçmelerinde etkili olan faktörlerin (bilinç dışı, meslek lisesi, mesleğin cazibesi) motivasyonları üzerindeki etkisini incelemiştir. Çalışmada demografik özelliklerin (cinsiyet ve yaş) motivasyon ürerinde anlamlı bir farklılı̆ga neden olmadığı ve yapılan regresyon analizi sonuçlarına göre muhasebe mesleği ile ilgili motivasyonu etkileyen en önemli unsurun muhasebe mesleğinin cazibesi olduğu belirlenmiştir.

Erduru vd., (2017), muhasebe meslek mensuplarının iş hayatında yaşadıkları mesleki tükenmiş̧liğin, iş tatmini üzerindeki etkisini incelemek amacıyla bir çalışma yapmışlardır. Çalışma evrenini Adana Hacı Sabancı Organize Sanayi Bölgesinde faaliyet gösteren işletmelerin muhasebe birimlerinde çalışan muhasebe meslek mensupları oluşturmaktadır. Çalışmada demografik özelliklere yönelik frekans analizleri, güvenirlik ve geçerlik analizleri, tanımlayıcı analizler ve çoklu regresyon analizi uygulanmıştır. Çalışmada mesleki tükenmişliğin iş tatminini \%7 oranında etkilediği, mesleki tükenmiş̧liğin alt boyutları olan "kişisel başarıda düşme hissi" ve "duyarsızlaşma" boyutlarının iş tatminini etkilemediği sadece "duygusal tükenme" boyutunun iş tatminini negatif yönde etkilediği sonucuna ulaşılmıştır. 
Karakaş vd., (2017), muhasebe meslek mensuplarının kişilik özelliklerinin mesleki bağlilığa ve iş tatminine olan etkisini incelemek amacıyla bir çalışma yapmışlardır. Çalışma kapsamında Bartın ilinde muhasebe mesleğini icra eden 208 meslek mensubuna anket uygulaması gerçekleştirilmiş, 174 meslek mensubunun geri dönüşü sağlanmıştır. Elde edilen verilerin analizi amacıyla çalışmada geçerlik ve güvenilirlik analizleri, tanımlayıcı analizler, korelasyon ve regresyon analizleri uygulanmıştır. Çalışmada korelasyon analizi sonuçlarına göre muhasebe meslek mensuplarının içsel ve dışsal iş tatminleri ile mesleki bağlllıkları arasında anlamlı ve pozitif ilişki tespit edilmiştir. Bununla birlikte çalışmada uygulanan regresyon analizi sonuçlarına göre muhasebe meslek mensuplarının kişilik özelliklerinin iş tatmini vasıtasıyla mesleki bağlılıklarını artırdığı belirtilmiştir.

Ng vd., (2017), Malezya'da öğrenim gören ve muhasebe eğitimi alan üniversite öğrencilerinin muhasebe mesleğine ve muhasebe kariyerine yönelik algılarını incelemek için bir çalışma yapmışlardır. Anket yönteminin uygulandığı çalışmaya 306 öğrenci katılım göstermiştir. Elde edilen verilerin analizinde geçerlilik ve güvenirlik analizi, frekans analizi, tanımlayıcı analizler, korelasyon analizi ve çoklu regresyon analizi gibi analiz yöntemlerinden yararlanılmıştır. Çalışmada uygulanan çoklu regresyon analizi sonuçlarına göre kişilerin içsel motivasyon unsurları (muhasebe mesleğine ilgi duyma, mesleği ilginç bulma vb.) ve muhasebe ile ilgili kişisel farkındalığın, muhasebe mesleğinin seçimini ve muhasebe alanında kariyer yapma düşüncesini olumlu yönde etkilediği sonucuna ulaşılmıştır.

Hai (2017), Vietnam'da faaliyet gösteren denetim firmalarında çalışan bağımlı muhasebe meslek mensuplarının iş tatmini etkileyen faktörleri incelemek amacıyla bir çalışma yapmıştır. 365 bağımlı meslek mensubunun katılım gösterdiği çalışmanın verileri anket yöntemi aracilığıyla elde edilmiştir. Çalışmada işletmelerin maaş politikalarının, oryantasyon ve eğitim faaliyetlerinin, muhasebe meslek mensuplarının üstleriyle olan ilişkilerinin, muhasebenin özünü temel alan niteliksel özelliklerinin muhasebe meslek mensuplarının iş tatminini pozitif ve anlamlı bir şekilde etkilediği sonucuna ulaşılmıştır. Ayrıca çalışmada elde edilen sonuçlara göre çalışma ortamı ve muhasebe meslek mensuplarının iş arkadaşlarıyla olan ilişkilerinin iş tatminine yönelik herhangi bir etkisi tespit edilememiştir.

Akyatan ve Kutluk (2015), muhasebe dersi alan üniversite öğrencilerinin etik karar verme süreçlerinde etkili olan faktörlerin ahlaki yaklaşımlarla ilişkisini incelemek amacıyla bir çalışma yapmışlardır. Bu doğrultuda Akdeniz Üniversitesi İktisadi ve İdari Bilimler Fakültesi İşletme ve Maliye bölümlerinde öğrenim gören ve muhasebe eğitimi alan öğrencilere anket yöntemi uygulanmıştır. Çalışmada güvenilirlik ve geçerlilik analizleri, varyans analizi ve hiyerarşik çoklu regresyon analizi yöntemi uygulanmıştır. Veriler üzerinde gerçekleştirilen analizlerde, kız öğrencilerin erkek öğrencilere göre etik bakış açılarının daha olumlu olduğu, "muhasebede etik" dersi alan öğrencilerin bu dersi almayan öğrencilere oranla etik değerlere daha bağlı oldukları sonucuna ulaşılmıştır.

Dursun vd., (2015), muhasebe meslek mensuplarının kişilik-iş uyumunun, iş- yaşam doyumu ve tükenmişlik düzeyi üzerine etkisini incelemek amacıyla bir çalışma yapmışlardır. Trabzon İl'inde faaliyet gösteren 141 muhasebe meslek mensubuna uygulanan anket yöntemi ile elde edilen verilerin analizinde frekans analizi, korelasyon ve regresyon analizi uygulanmıştır. Çalışmaya göre kişilikleri ile yapmış oldukları meslekleri uyumlu olan bireylerin iş doyumu ve tatmini de yüksek olmaktadır. Çalışmada ayrıca meslek seçiminde kariyer planlamasının önemine yer verilmiş, meslek seçiminde bireysel özelliklerin dikkate alınması gerekliliği belirtilmiştir.

Wen vd., (2015), Çin'de öğrenim gören ve muhasebe eğitimi alan üniversite öğrencilerinin muhasebe mesleğini seçmelerini etkileyen faktörleri incelemek amacıyla bir çalışma yapmışlardır. 288 öğrencinin katılım gösterdiği anket çalışması ile elde edilen veriler SPSS-19 paket programı ile analize tabi tutulmuştur. Çalışmada uygulanan lojistik regresyon analizi sonuçlarına göre muhasebe mesleğinin kişilere sağladığı sosyal statü ve iş firsatlarının mesleğin seçiminde olumlu bir etkisi olmadığı tespit edilmiştir. Bununla birlikte muhasebe mesleğinin kişilere sağladığı gelir, mesleğin çekiciliği, bağımsız çalışma ortamı, meslek ile ilgili aile, arkadaş, rol model gibi kişilerin telkininin muhasebe mesleğinin seçiminde kişiler üzerinde olumlu etkisi olduğu sonucuna ulaşılmıştır.

Dibabe vd., (2015), Bahir Dar Üniversitesinde öğrenim gören işletme bölümü öğrencilerinin muhasebe mesleğini seçmelerini etkileyen faktörleri incelemek amacıyla bir çalışma yapmışlardır. 197 öğrencinin katılım gösterdiği çalışmada veri toplama yöntemi olarak anket yöntemi uygulanmıştır. 
Çalışmada uygulanan lojistik regresyon analizi sonuçlarına göre bireylerin içsel faktörlerinin (yetenek, yaratıc1lı, vb.) ile muhasebe alanında kariyer yapma düşüncesini olumlu ve anlamlı bir şekilde etkilediği soncuna ulaşılmıştır. Ayrıca muhasebe mesleğinin çalışma koşulları, kazanç durumu, bireylere yasal sorumluluklar yüklemesi, bireylere sağladığı deneyim firsatlarının da muhasebe alanında kariyer yapma düşüncesini olumlu bir şekilde etkilediği belirtilmiştir.

Kaplanoğlu (2014), muhasebe meslek mensuplarında iş yüküne veya farklı değişkenlere bağlı olarak ortaya çıkan mesleki stresin nedenlerini belirlemek ve bu nedenlerin mesleki sonuçlarla ilişkisini incelemek amacıyla bir çalışma yapmıştır. Bu doğrultuda, Manisa İl'inde faaliyet gösteren 319 meslek mensubuna anket uygulanmıştır. Çalışma kapsamında gerçekleştirilen regresyon analizi sonuçlarına göre işe bağlı gerginlikler ile nitel aşırı rol yükü arasında; iş tatmini ile rol çatışması, rol belirsizliği arasında anlamlı ilişkiler tespit edilmiştir. Ancak iş değiştirme niyeti ile hiçbir faktör arasında anlamlı ilişki tespit edilememiştir.

Buky Folami vd., (2014), muhasebe meslek mensuplarının örgütsel bağl1lıklarını etkileyen faktörleri incelemek amacıyla bir çalışma yapmışlardır. Bu doğrultuda Amerika Birleşik Devletleri’nde ulusal ve uluslararası ölçekte faaliyet gösteren denetim firmalarında çalışan muhasebe meslek mensuplarına anket çalışması uygulanmış ve 503 adet anket çalışma kapsamında analize tabi tutulmuştur. Çalışmada elde edilen bulgulara göre işletmelerde uygulanan kural ve prosedürlerin muhasebe meslek mensuplarının örgütsel bağll1ıklarının olumlu yönde etkilediği sonucuna ulaşılmıştır. Çalışmaya göre örgüt yapılarındaki hiyerarşik esneklik ise muhasebe meslek mensuplarının örgütsel bağll1ıkları üzerinde negatif etkiye sahiptir. Bunula birlikte muhasebe meslek mensuplarının kurum içerinde çalıştıkları süre arttıkça örgütsel bağlılıkları da aynı şekilde artış göstermektedir.

Mustapha ve Hassan (2012), Malezya'da öğrenim gören üniversite öğrencilerinin muhasebe mesleğine yönelik algılarını incelemek amacıyla bir çalışma yapmışlardır. 103 öğrencinin katılım gösterdiği çalışmada veri toplama yöntemi olarak anket yöntemi tercih edilmiştir. Çalışmada özellikle mezun olma aşamasında olan öğrencilerin algılarının incelenmesindeki nedenin, bu öğrencilerin muhasebe bilgi düzeylerinin yüksek olması ve kariyer seçiminde daha bilinçli hareket etmeleri olarak belirtilmiştir. Çalışmada uygulanan regresyon analizi sonuçlarına göre muhasebe mesleğinin uzun yıllar ifa edilebilecek bir meslek olması ve bu süreçte kişilere deneyim ve tecrübe katarak alanında söz sahibi ve güvenilir bir meslek mensubu olma gibi firsatlar vermesinin muhasebe mesleği üzerindeki algiları olumlu yönde etkilediği sonucuna varılmıştır. Çalışmada ayrıca yapılacak çalışmalara yol göstermesi açısından, kişilerin kültürel özellikleri ve akademik başarısı gibi faktörlerin muhasebe mesleği üzerindeki etkilerinin de incelenebileceği belirtilmiştir.

Öztürk vd., (2011), muhasebe meslek mensuplarının mesleki tükenmişlik düzeylerinin iş bağl11ıkları üzerindeki etkisini incelemek amacıyla bir çalışma yapmışlardır. Bu doğrultuda Ankara ilinde bağımsız muhasebeci olarak faaliyet gösteren 462 meslek mensubuna anket uygulanmıştır. Çalışmada elde edilen sonuçlara göre muhasebe meslek mensuplarının tükenmişlik seviyesi ile işe bağl1lıkları arasında ters bir ilişki tespit edilmiştir. Ayrıca çalışmada gerçekleştirilen regresyon analizi sonuçlarına göre muhasebe meslek mensuplarının kişisel başarıda düşme hissinin artmasının işe bağlılık düzeyini düşürdüğü saptanmıştır.

Chen ve Silverthone (2008), kontrol odağının muhasebe meslek mensuplarının iş stresi, iş performansı ve iș tatmini üzerindeki etkisini incelemek amacıyla bir çalışma yapmışlardır. Çalışmanın verilerini Tayvan'da çeşitli işletmelerde bağımlı muhasebeci olarak çalışan 209 muhasebe meslek mensubunun geri dönüşüyle elde edilen anket formları oluşturmaktadır. Çalışmada uygulanan regresyon analizi sonuçlarına göre dâhili kontrol odağı muhasebe meslek mensuplarının iş stresi üzerinde negatif, iş performansı üzerinde pozitif etkiye sahiptir. Harici kontrol odağı ise muhasebe meslek mensuplarının iş stresini artırırken, iş performansını ve is tatminini olumsuz yönde etkilemektedir. Çalışmada ayrıca, kullanılan değişkenlerin değiştirilerek farklı meslekler için de çalışmalar yapılabileceği veya farklı ülkelerde yapılacak muhasebe meslek mensuplarına yönelik çalışmaların sonuçları genelleştirebileceği belirtilmiştir.

Sugahara vd., (2008), Avustralya'da öğrenim gören işletme bölümü öğrencilerinin muhasebe derslerini seçmelerini etkileyen faktörleri incelemek amacıyla bir çalışma yapmışlardır. 114 öğrencinin katılım gösterdiği çalışmada veriler anket yöntemi aracılığıyla elde edilmiştir. Çalışmada uygulanan 
lojistik regresyon analizi sonuçlarına göre muhasebenin kişilere sağladığı entelektüel bakış açısı, kişileri yaratıcı bir şekilde düşünmeye teşvik etmesi, muhasebenin iş hayatında birçok farklı alanda çalışma olanakları sunması ve muhasebenin sayısal işlemlere dayalı dikkat isteyen bir bilim dalı olmasının kişilerin muhasebe derslerini seçmelerinde olumlu etkisi olduğu tespit edilmiştir. Çalışmada ayrıca Avustralya kökenli öğrencilerin Çin ve diğer Asya kökenli öğrencilere göre yaratıc1lık seviyelerinin daha yüksek olduğu, dolayısıyla muhasebe dışında yaratıcılıklarını kullanabilecekleri alanlara yönelme eğilimlerinin yüksek olduğu belirtilmiştir.

Tan ve Laswad (2006), Yeni Zelanda'da öğrenim gören üniversite öğrencilerinin muhasebe mesleğine yönelik algılarını planlı davranış modeli çerçevesinde imcelemek amacıyla bir çalışma yapmışlardır. 1422 öğrencinin katılım gösterdiği çalışmada, öğrencilerin muhasebe mesleğine yönelik algılarının belirlenmesinde kişisel tutumlarının, aile, arkadaş, üniversitesi hocası gibi rol model alınan referans gruplarının ve muhasebe mesleğinin fonksiyonel özelliklerinin olumlu etkisi olduğu tespit edilmiş̧ir. Çalışma da ayrıca Yeni Zelandalı öğrencilerin, Yeni Zelanda'da öğrenim gören yabancı öğrencilere göre muhasebe mesleğinin çalışanlara sunduğu aylık kazanç, geniş çalışma olanağı ve gelecekte maddi anlamda belli bir refah seviyesine ulaşma gibi imkânlara daha olumlu baktığı belirtilmiştir. Bununla birlikte Yeni Zelanda'da öğrenim gören yabancı öğrencilerin, Yeni Zelandalı öğrencilere göre muhasebe mesleğini sıkıcı bir meslek olarak nitelendirdiği de çalışmada tespit edilen sonuçlar arasındadır.

\section{SONUC}

Çalışmada muhasebe eğitimi alan üniversite öğrencilerinin muhasebe derslerine yönelik başarılarını, muhasebe bilimine yönelik kariyer süreçlerini ve muhasebe mesleğini seçmelerini etkileyen faktörler ile muhasebe meslek mensuplarının iş tatmini, iş performansı ve başarısını etkileyen faktörleri konu edinen 20 yerli, 20 yabancı çalışma incelenmiştir. İncelenen çalışmalarda özellikle regresyon analizi yöntemi kullanılan çalışmalar tercih edilmiştir. İncelenen çalışmalarda da görülebileceği üzere kişiler meslek seçiminde çeşitli faktörlerden etkilenmektedir. Bu bazen mesleğe yönelik maddi beklentiler olabileceği gibi bazen de aile, arkadaş, rol model gibi kişinin sosyal çevresi olmaktadır. Bununla birlikte muhasebe mesleği seçimini etkileyen faktörler kültürlere ülkelere, bölgelere göre de farklılık göstermektedir. Aynı ülkede yapılan iki çalışmadan birinde muhasebe mesleğinin bireylere sunduğu geniş iş olanağı meslek seçiminde olumlu bir etken iken bir diğer çalışmada mesleğin kişiye sunduğu kazanç meslek seçiminde önemli bir faktör olabilmektedir. Benzer şekilde muhasebe meslek mensuplarının iş tatmini, iş performansını ve iş başarısını etkileyen faktörlerin de kültürlere, ülkelere, bölgelere göre farklılık gösterdiğini söylemek yanlış olmayacaktır. Nitekim meslekler her ülkede aynı değeri görmemektedir. Bununla birlikte ülkelerin yasal ve politik düzenleri mesleklere olan ilgiyi ve beraberinde o meslekteki başarıyı da etkileyebilmektedir. Nitekim muhasebe meslek mensuplarının verecekleri kararlarda mükellef, devlet ve amirleri arasında kalması çok görünen bir durumdur.

$\mathrm{Bu}$ çalışma, muhasebe eğitimi alan öğrencilerin ve muhasebe meslek mensuplarının kariyer süreçlerine yönelik objektif bilgiler sunmaktadır. Farklı mesleklere veya sektörlere yönelik olarak yapılacak derleme çalışmaları da ilgili alanlara yönelik objektif bakış açıları kazandıracaktır.

\section{Kaynakça}

Abdelmoula, L. (2020), "The Impact of Extrinsic Job Satisfaction Factors on the Organizational Commitment of Accounting Professionals in Tunisia". Management Science Letters. 10: ss. 3003-3008.

Aksu, İ., Tursun, M. (2018), "Muhasebe Eğitimi Alan Öğrencilerin Motivasyon ve Beklenti Düzeylerinin Akademik Başarılarına Etkisi”. Akademik Yaklaşımlar Dergisi. 9 (2): ss. 17-31.

Aktaş, A., Saraçbaşi, O., (2005), Negatif Binom RegresyonModeli, VIII. Ulusal Biyoistatistik Kongresi, 20-22 Eylül 2005, Bursa, ss. 124 - 129.

Akyatan, A., Kutluk, F.A. (2015), "Muhasebe Dersi Alan Öğrencilerin Etik Karar Alma Sürecini Etkileyen Faktörler Üzerine Bir Araştırma". Journal of Accounting, Finance and Auditing Studies. 1 (4): ss. 42-66. 
Altunışık, R., Coşkun, R., Bayraktaroğlu, S., Yıldırım, E. (2010), Sosyal Bilimlerde Araştırma Yöntemleri SPSS Uygulamalı. Altıncı Baskı. Sakarya: Sakarya Yayıncılık.

Apal1, A., Acun, Ö. (2019), "Muhasebe Eğitimi Alan Öğrencilerde Yeşili Koruma Bilincinin Yeşil Muhasebe Üzerindeki Etkisinin Araştırılması". Oğuzhan Sosyal Bilimler Dergisi. 1 (1): ss. 1836 .

Arı, A., Önder, H. (2013), "Farklı Veri Yapılarında kullanılabilecek Regresyon Modelleri”, Anadolu Tarım Bilim Dergisi, 28 (3): ss. 168-174

Arif, S., Iqbal, J., Khalil, U. (2019), "Factors Influencing Students' Choices of Academic Career in Pakistan”. FWU Journal of Social Sciences. 13 (1): ss. 35-47.

Ayboğa, H., (2003) "Globalleşme Sürecinde Ülkemizde Muhasebe Mesleği ve Meslek Mensuplarının Eğitimi”. Marmara Üniversitesi İktisadi ve İdari Bilimler Dergisi. 18(1): ss. 327-359.

Aydemir, O. (2015), "Muhasebe Meslek Mensuplarının Karşılaştıkları Sorunlar Ve Beklentiler”. Muhasebe ve Finansman Dergisi. 67: ss. 71-84.

Bekoe, R. A., Owusu, G. M. Y., Ofori, C. G., Essel-Anderson, A., Welbeck, E. E. (2018), "Attitudes Towards Accounting and Intention to Major in Accounting: a Logistic Regression Analysis". Journal of Accounting in Emerging Economies. 8 (4): ss. 459- 475.

Buky Folami, L., Asare, K., Kwesiga, E., Bline, D. (2014), "The Impact of Job Satisfaction and Organizational Context Variables on Organizational Commitment." International Journal of Business \& Public Administration. 11 (2): ss. 1- 18.

Bulutoding, L., Majid, J., Suwandi, M., Salam, S. (2020), “Analysis of Factors Affect the Understanding of International Financial Reporting Standard (IFRS) of Accounting Students of Higher Education in Makassar". International Journal of English Literature and Social Sciences. 5 (2): ss. $427-433$.

Büyükyılmaz, O., Vargün, H., Uygurtürk, H. (2018), "Mesleki Bağl1lı̆̆ın İştatmini Üzerindeki Etkisi: Muhasebe Meslek Mensuplan Üzerine Bir Araştırma”. Kafkas Üniversitesi İktisadi ve İdari Bilimler Fakültesi Dergisi. 9 (17): ss. 53- 71.

Cengiz, S., Tekin, B. (2019), "Lisans Düzeyinde Muhasebe Eğitimi Alan Öğrencilerde Strese Neden Olan Faktörlerle Derse Yönelik Tutumları Arasındaki İlişkinin Araştırılması”. Muhasebe ve Finansman Dergisi. 81: ss. 183- 212.

Chen, J.-C., Silverthorne, C. (2008), "The Impact of Locus of Control on Job Stress, Job Performance and Job Satisfaction in Taiwan". Leadership\&Organization Development Journal. 29 (7): ss. $572-582$.

Çarıkçı, O. (2017a), "Muhasebe Eğitimi Almakta Olan Öğrencilerin Muhasebe Mesleğine Yönelik Tutumlarının Sektörde Çalışma Niyetine Etkisi”. Muhasebe ve Finansman Dergisi. 76: ss. 221238.

Çarıkçı, O. (2017b), "Muhasebe Eğitimi Almakta Olan Öğrencilerin Motivasyonları ve Muhasebe Bölümünü Tercihlerinin İrdelenmesi”. Süleyman Demirel Üniversitesi İktisadi ve İdari Bilimler Fakültesi Dergisi. 22 (4): ss. 1223-1233.

Cox, R., (1983), Some Remarks on Overdispersion. Biometrika,70: ss. 269-274.

Demir, İ., Temelli, F. (2019), "Muhasebe Eğitimi Alan Öğrencilerin Motivasyon ve Beklentilerinin Değerlendirilmesi: Ağrı İbrahim Çeçen Üniversitesi Örneği”. Erzurum Teknik Üniversitesi Sosyal Bilimler Enstitüsü Dergisi. 9: ss. 33-50.

Deniz, Ö. (2005), Poisson Regresyon Analizi. İstanbul Ticaret Üniversitesi Fen Bilimleri Dergisi Y11:4 Say1:7 Bahar 2005/1: ss. 59-72.

Dibabe, T. M., Wubie, A. W., Wondmagegn, G. A. (2015), "Factors that Affect Students' Career Choice in Accounting: A Case of Bahir Dar University Students". Research Journal of Finance and Accounting. 6 (5): ss. 146-153. 
Durgut, M., Pehlivan, M. (2019), "Muhasebe Öğrencilerinin Meslek Seçimini Etkileyen Faktörlerin Analizi". Karadeniz Teknik Üniversitesi Sosyal Bilimler Enstitüsü Sosyal Bilimler Dergisi. 9 (17): ss. 103- 118 .

Dursun, S., Kaya, U., İştar Işıklı, E. (2015), "Kişilik- İş Uyumunun Duygusal Tükenmişlik İle İş ve Yaşam Doyumu Üzerindeki Etkisi: Muhasebe Meslek Mensupları Üzerinde Bir Uygulama". Karadeniz Teknik Üniversitesi Sosyal Bilimler Enstitüsü Sosyal Bilimler Dergisi. 5 (9): ss. 5569.

Erdoğan, M., Dinç, E. (2009), “Türkiye Muhasebe Standartları ve Muhasebe Meslek Mensuplarının Bilgi Düzeylerinin İncelenmesi”. Muhasebe ve Finansman Dergisi. 43: ss. 154-169.

Erduru, İ., Deran, A., Uzun, E. (2017), “Muhasebe Meslek Mensuplarının Mesleki Tükenmişliğinin İş̧ Tatmini Üzerine Etkilerinin Değerlendirilmesi: Adana Hacı Sabancı Organize Bölgesinde Bir Araştırma”. Ömer Halisdemir Üniversitesi İktisadi ve İdari Bilimler Fakültesi Dergisi. 10 (2): ss. 158- 176.

Gör, Y. (2017), "Farklı Eğitim Programındaki Öğrencilerin Finansal Muhasebe Dersine İlişkin Algılarına Yönelik Bir Uygulama: Çankırı Örneği”. Uluslararası Yönetim İktisat ve İşletme Dergisi. Özel Say1. ss. 351- 368.

Gündüz, M., Özen, E. (2016), "Muhasebe Meslek Mensuplarının Sorunları ve Mesleki Memnuniyetlerinin Analizi: Uşak İli Örneğì". Muhasebe ve Finansman Dergisi. 70: ss. 67- 90.

Güneş, R., Durmuş, A. F., Solak, B. (2012), "Küreselleşmenin Muhasebe Uygulamalarına Etkisi”. Akademik Yaklaşımlar Dergisi. 3(2): ss. 57-66.

Hacırüstemoğlu, R. (2009), “Türkiye'de Muhasebe Eğitimi İçin On Y1llık Hedefler”. Muhasebe Bilim Dünyası Dergisi. 11(3): ss. 19-32.

Hai, P. T. (2017), "The Research of Factors Affecting the Job Satisfaction of Auditors in Auditing Firms: Empirical Evidence in Vietnam". International Journal of Economic Research. 14 (9): ss. $315-$ 328.

Harun, A. (2020), "Analysis of Accounting Student Perceptions towards the Desirefor a Career as Qualified Accountants: Case Study on Higher Education in Medan". Research Journal of Finance and Accounting. 11 (2): ss. 95-104.

Hasim, F., Darmayanti, N., Dientri, A. M. (2020), "Analysis of Factors that Influence Accounting Students Choose Career As A Public Accountant”. Journal of Auditing, Finance and Forensic Accounting. 8 (1): ss. 19- 26.

Herawati, N. T., Candiasa, I M., Yadnyana, I K., Suharsono, N. (2018), "Factors That Influence Financial Behavior Among Accounting Students in Bali". International Journal of Business Administration. 9 (3): ss. 30-38.

Kaplanoğlu, E. (2014), "Mesleki Stresin Temel Nedenleri Ve Muhtemel Sonuçları: Manisa İlindeki SMMM'ler Üzerine Bir Araştırma". Muhasebe ve Finansman Dergisi. 64: ss. 131- 150.

Karakaş, A., Saban, M., Aslan, A. (2017), "Muhasebe Meslek Mensuplarının Kişilik Özelliklerinin İş Tatmini ve Mesleki Bağlılıklarına Etkisi". Mali Çözüm Dergisi. ss. 41-62.

Kılınçarslan, T. B., Küçüksüleymanoğlu, R. (2019), "Muhasebe Meslek Mensuplarının Örgütsel Bağlılıklarının İş Tatmini Üzerindeki Etkisi”. Muhasebe Bilim Dünyası Dergisi. 21 (4): ss. 1078-1090.

Mosuin, E., Mat, T. Z. T., Ghani, E. K., Alzeban, A., Gunardi, A. (2019), “Accountants' Acceptance of Accrual Accounting Systems in the Public Sector and its Influence on Motivation, Satisfaction and Performance". Management Science Letters. 9: ss. 695-712.

Mustapha, M., Hassan, M. H. A. (2012), “Accounting Students' Perception on Pursuing Professional Examination". International Journal of Education. 4 (4): ss. 1-15. 
Nakip, M. (2013), Pazarlama Araştırmalarına Giriş (SPSS Uygulamalı), Dördüncü Baskı. Seçkin Yayıncilik.

Ng, Y.-H., Lai, S.-P., Su, Z.-P., Yap, J.-Y., Teoh, H.-Q., Lee, H. (2017), "Factors Influencing Accounting Students' Career Paths". Journal of Management Development. 36 (3): ss. 319- 329.

Nguyen, D. H. (2020), “An Analysis of Underlying Constructs Affecting the Job Satisfaction Amongst Accountants". Management Science Letters. 10: ss. 1069- 1076.

Özarıcı, Ö. (1996), Farklı Not Sistemlerinde Öğrencinin Başarılı Olma Olasılığının Probit Regresyon Analiziyle Değerlendirilmesi, Osmangazi Üniversitesi Fen Bilimleri Enstitüsü, Yüksek Lisans Tezi, Eskişehir.

Özdemir, F. S., Bulut, E., Ünal, İ. H. (2018), "Muhasebe Dersi Alan Öğrencilerin Matematiğe Bakış Açısı ve Akademik Başarıları". Ömer Halisdemir Üniversitesi İktisadi ve İdari Bilimler Fakültesi Dergisi. 11 (4): 143-161.

Özkan, K. (2009), Toprağın Tarla Kapasitesi Değişiminin Toprak Türüne Göre Temel Bileşenler Regresyon Analizi İle Modellenmesi Süleyman Demirel Üniversitesi Orman Fakültesi Dergisi Seri: A, Say1: 2, Issn: 1302-7085, ss. 1-9.

Öztürk, V., Koçyiğit, S. Çil, B., Emine Ç. (2011), "Muhasebe Meslek Mensuplarının Mesleki Tükenmişlik Düzeyleri İle İşe Bağlılık Arasındaki İlişkiyi Belirlemeye Yönelik Bir Araştırma: Ankara İli Örneği”. Doğuş Üniversitesi Dergisi. 12 (1): ss. 84- 98.

Shan, T. Y., Rou, W. J., N., Radha K. (2019), "Factors Influencing Accounting Students in UCSI University in Choosing Internal Audit as Their Career Options". Proceedings of the $20192^{\text {nd }}$ International Conference on E-Business, Information Management and Computer Science.

Srirejeki, K., Supeno, S., Faturahman, A. (2019), "Understanding the Intentions of Accounting Students to Pursue Career as a Professional Accountant”. Binus Business Review. 10 (1): ss. 11- 19.

Sugahara, S., Boland, G., Cilloni, A. (2008), "Factors Influencing Students' Choice of anAccounting Major in Australia". Accounting Education: an International Journal. 17: ss. 37-54.

Tan, L. M., Laswad, F.(2006), "Students' Beliefs, Attitudes and Intentions to Major in Accounting". Accounting Education: an International Journal. 15 (2): ss. 167- 187.

Tekin, B., Deniz, B. (2019), "Muhasebe Meslek Mensuplarının İş Stresi, İş Performansı ve İş Tatmini Düzeyleri Üzerinde Kontrol Odağı Etkili Bir Faktör mü?”. Muhasebe ve Finansman Dergisi. 84: ss. 65- 94.

Temelli, F. (2019), “Öğrencilerin Muhasebe Derslerinde Teknoloji Kullanımına Yönelik Tutumlarının, Derse Odaklanma ve İlgileri Üzerine Etkisinin Faktör Analizi ve Yapısal Eşitlik Modeli ile İncelenmesi: Ağrı İbrahim Çeçen Üniversitesi İ̈BF Örneği”, Manas Sosyal Araştırmalar Dergisi, 8 (4): ss. 3651-3667.

Temelli, F., Çınar, Ö. (2018), "İ̈BF Öğrencilerinin Maliyet Muhasebesi Dersine Yönelik Başarı ve Tutumları Arasındaki İlişki: Ağrı İbrahim Çeçen Üniversitesi’nde Bir Uygulama”. Anemon Muş Alparslan Üniversitesi Sosyal Bilimler Dergisi. 6 (4): ss. 559- 567.

Topcu, Y. (2008), Çiftçilerin Tarımsal Destekleme Politikalarından Faydalanma İstekliliğinde Etkili Faktörlerin Analizi: Erzurum İli Örneği. Akdeniz Üniversitesi Ziraat Fakültesi Dergisi, 21(2), ss. $205-212$

Türel, A. (2011), Worldcom Skandal1: Muhasebe Hileleri. İstanbul: Türkmen Kitabevi.

Türker, M. (2018), "Dijitalleşme Sürecinde Küresel Muhasebe Mesleğinin Yeniden Şekillenmesine Bakış". Muhasebe Bilim Dünyası Dergisi. 20(1): ss. 202-235.

Vural, A. (2007), Aykırı Değerlerin Regresyon Modellerine Etkileri ve Sağlam Kestiriciler. Marmara Üniversitesi Sosyal Bilimler Enstitüsü, Yüksek Lisans Tezi, İstanbul 
Wen, L., Hao, Q., Bu, D. (2015), "Understanding the Intentions of Accounting Students in Chinato Pursue Certified Public Accountant Designation". Accounting Education: an International Journal. 24 (4): ss. 341-359. 